\title{
ECOLOGICAL STUDIES ON THE BUTTERFLY MANIOLA JURTINA IN BRITAIN. II. POPULATION DYNAMICS: THE PRESENT POSITION
}

\author{
BY PAUL M. BRAKEFIELD
}

Department of Genetics, University of Liverpool, Brownlow Street, Liverpool L69 3 BX

\section{SUMMARY}

(1) Capture-recapture experiments were performed to investigate the population dynamics of Maniola jurtina. The main study site was at Hightown near Liverpool with additional sites in this area and in central-eastern Scotland.

(2) Adult survival at Hightown was lowest in the hot and dry summer of 1976. The estimates of expectation of life for males and females in all experiments varied between 5 and 12 days.

(3) The mean number of eggs laid by a female was estimated from fertility and survivorship data as 66 . This is 0.37 of the mean total egg production in the laboratory.

(4) Analysis of the rate of capture of newly emerged butterflies at Hightown suggested that the emergence of each sex occurred in more than one peak in 1977 and 1978.

(5) Total emergence at Hightown estimated using two capture-recapture models declined from $1380-1850$ insects $\mathrm{ha}^{-1}$ in 1976 to $235-250$ insects ha ${ }^{-1}$ in 1977 . This change was probably due to exceptionally high mortality of hatching larvae in the dry late summer of 1976. A generally lower population density was found in Scotland than in England.

(6) The results are compared with those of other authors. Factors which introduce error into the estimates are examined.

\section{INTRODUCTION}

The early work on the population dynamics of Maniola jurtina (L.) in the Isles of Scilly was primarily concerned with the development of sequential mark-release-recapture experiments and demonstrating their value to ecological geneticists (Dowdeswell, Fisher \& Ford 1949; Ford 1975). Two more recent studies on the English mainland, in the Wyre Forest (Tudor \& Parkin 1979) and at Monks Wood (Pollard 1981), used more refined techniques such as the application of individual-specific marks. However, sampling errors were large and the data were not adequately examined in relation to the assumptions made by capture-recapture models. This paper describes a more detailed investigation of parameters of adult survival rate and population size at a number of sites in Britain.

\section{METHODS}

The main study sites near Liverpool and the design of the mark-release-recapture experiments performed at each are described by Brakefield (1982a). Brief details of the length of the experiments and the number of butterflies released and recaptured are given in

Present address: Department of Biological Sciences, University of Exeter, Perry Road, Exeter EX4 4QG. 
TABLE 1. Some details of capture-recapture experiments performed with Maniola jurtina

Length of experiment

\begin{tabular}{|c|c|c|c|c|c|c|c|c|}
\hline \multirow[b]{2}{*}{ Population } & \multirow[b]{2}{*}{ Year } & \multirow{2}{*}{$\begin{array}{c}\text { Number } \\
\text { of } \\
\text { days }\end{array}$} & \multirow{2}{*}{$\begin{array}{c}\text { Portion } \\
\text { of } \\
\text { flight } \\
\text { period }\end{array}$} & \multirow{2}{*}{$\begin{array}{l}\text { Number of } \\
\text { butterflies } \\
\text { released* }\end{array}$} & \multicolumn{2}{|c|}{$\begin{array}{l}\text { Butterflies } \\
\text { recaptured }\end{array}$} & \multirow{2}{*}{$\begin{array}{c}\text { Total days } \\
\text { survived } \\
\text { by marks } \dagger\end{array}$} & \multirow{2}{*}{$\begin{array}{c}\text { Mean daily } \\
\text { sampling } \\
\text { fraction } \neq \\
( \pm \text { S.E. })\end{array}$} \\
\hline & & & & & Number & $\%$ & & \\
\hline \multicolumn{9}{|l|}{ Males } \\
\hline West Kirby & 1975 & 11 & early to mid. & 175 & 56 & 32.0 & 307 & $0.36 \pm 0.06$ \\
\hline Hightown & 1976 & 14 & early and mid.§ & 414 & 113 & $27 \cdot 0$ & 634 & 0.18 \\
\hline Hightown & 1977 & 18 & early to mid. & 98 & 78 & 79.6 & 2397 & $0.57 \pm 0.06$ \\
\hline Hightown & 1978 & 25 & early to mid. & 64 & 50 & 78.1 & 4410 & $0.59 \pm 0.06$ \\
\hline Hall Road & 1978 & 25 & early to mid. & 567 & 180 & 31.8 & 3186 & $0.18 \pm 0.03$ \\
\hline Females & & & & & & & & \\
\hline West Kirby & 1975 & 8 & earl & 63 & 21 & 33 & 64 & $0.46 \pm 0.11$ \\
\hline Hightown & 1976 & 14 & early and & 451 & 143 & 32 & 1184 & $0.19 \pm 0.03$ \\
\hline Hightown & 1977 & 17 & early to mid. & 26 & 19 & $73 \cdot 1$ & 226 & $0.60 \pm 0.14$ \\
\hline Hightown & 1978 & 19 & early to mid. & 37 & 27 & 73.0 & 493 & $0.59 \pm 0.07$ \\
\hline
\end{tabular}

* Excludes butterflies captured for the first time on the final day of the experiment.

+ A mark is assumed to be given at each capture.

$¥$ Each daily estimate is calculated by dividing the sample size (when $>5$ ) by the Fisher \& Ford estimate of daily population size.

\$ The middle flight period was covered by a multiple capture-recapture experiment. A Lincoln index estimate for population size was obtained in the early flight period.

Table 1 . The flight period of $\boldsymbol{M}$. jurtina begins sometime in June or early July and is $2-3$ months long.

The models of Fisher \& Ford (1947), of Jolly (1965) and of Manly \& Parr (1968) are frequently used to estimate parameters of survival rate and population size. Initial inspection of the capture-recapture data revealed a high rate of recapture (Table 1) suggesting that analysis by the stochastic model of Jolly was appropriate (see Begon 1979; Blower, Cook \& Bishop 1981). However, in some experiments particularly on females, the numbers handled were small and hence sampling errors large. Under such conditions the deterministic model of Fisher \& Ford is likely to be more appropriate (Bishop \& Sheppard 1973; Sheppard \& Bishop 1973).

Both Fisher \& Ford's and Jolly's models assume that survival is independent of an animal's age, whereas Manly \& Parr's model takes account of age-dependent mortality. Each cohort of Maniola jurtina whose history could be followed for at least 8 days shows a similar survivorship curve (Fig. 1), with a period of constant survival with increasing age followed by a period of senescence during which the probability of survival declines with age. For the two cohorts followed in 1976 the relatively early onset of senescence is, at least partly, an artefact due to the experiment commencing in the middle flight period (Table 1). The cohorts for 1978 do not show a departure from age-dependent mortality until at least 15 days after emergence. For males at Hall Road $(n=111)$ less than $10 \%$ were still alive when senescence became evident. Because of this and since the experiments were not longer than 25 days the effect of age-dependent mortality on the estimates obtained by Fisher \& Ford's and Jolly's methods will be small. Therefore, it was not considered necessary to use Manly \& Parr's model in the present analyses since its performance is inferior to that of Jolly's model in the absence of age-dependent mortality (Manly 1970), and because it divides recapture data into smaller categories than other models and hence is more sensitive to sampling error (Blower, Cook \& Bishop 1981). Some further estimates of survival rate were obtained by using the maximum likelihood 

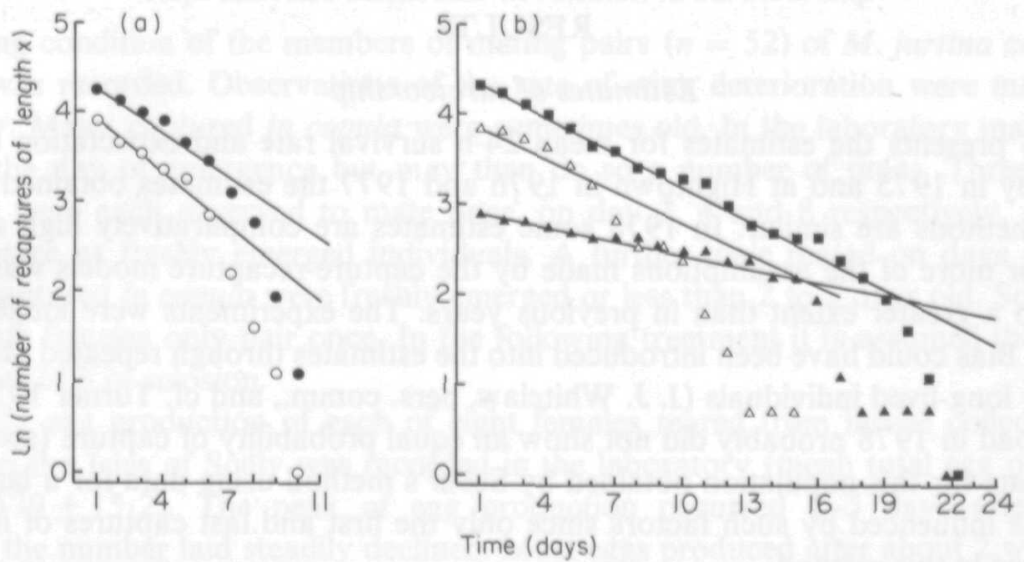

Fig. 1. Natural logarithm of number of Maniola jurtina known to have survived for the indicated length of time. Lines are fitted by eye through the points which approximate to periods of constant survival. Only butterflies released over the first 3-5 days of each experiment are analysed. (a) Hightown 1976; - females; O, males. (b) Hightown, males $\triangle, 1977 ; \mathbf{\Delta}, 1978$. Hall Road, males; $\mathbf{E}, 1978$.

method of Seber $(1973$, p. 413$)$ to analyse the data plotted in Fig. 1 for the estimated period of constant survival.

Each model assumes that all animals in the population are equally likely to be captured. Application of Leslie's (1958) test of equal catchability (Table 2) shows that in some populations all individuals do not have an equal probability of capture. Possible consequences of differences in catchability are considered later. Further details of the checks of assumptions are given elsewhere (Brakefield 1979, 1982a).

TABLE 2. Leslie's (1958) test of randomness of sampling in marked populations of Maniola jurtina (data were selected to obtain maximum samples sizes and in accordance with Leslie's suggestions)

Males

Females

Length of Number
study period (days) insects

Hightown, 1976

3 23

$30 \cdot 86$

Chisquare study period of (days) insects

Chisquare

Hightown, 1977

$\begin{array}{llll}4 & 25 & 43 \cdot 10^{* *} & \text { insufficient data } \\ 3 & 29 & 42 \cdot 74^{*} & \end{array}$

Hall Road, 1978

$\begin{array}{lll}6 & 22 & 29.32 \\ 5 & 27 & 38.67 \dagger \\ 4 & 32 & 46.50^{*} \\ 3 & 36 & 50 \cdot 88^{*}\end{array}$




\section{RESULTS \\ Estimates of survivorship}

Table 3 presents the estimates for mean 24-h survival rate and expectation of life. At West Kirby in 1975 and at Hightown in 1976 and 1977 the estimates obtained using the different methods are similar. In 1978 some estimates are comparatively high suggesting that one or more of the assumptions made by the capture-recapture models was violated, perhaps to a greater extent than in previous years. The experiments were longer in 1978 (Table 1). Bias could have been introduced into the estimates through repeated recapture of some very long-lived individuals (J. J. Whitelaw, pers. comm., and cf. Turner 1971). Males at Hall Road in 1978 probably did not show an equal probability of capture (see Table 2). The estimate for this population obtained by Sèber's method using data for a large cohort will be less influenced by such factors since only the first and last captures of individuals are analysed in this method.

The estimates in Table 3 indicate no obvious difference in survival between the sexes. An analysis of variance of Jolly's estimates of daily survival at Hightown in 1976 that uses the sex X date interaction as an estimate of the error variance (see Bishop \& Hartley 1976) shows no evidence for such a difference $(F=0.33$, d.f. 1 and $7, P>0 \cdot 1)$. The survivorship curves for males and females in this population are similar (Fig. 1). The analysis of variance also shows no evidence for differences in survival during the various intersampling periods $(F=1 \cdot 49$, d.f. 7 and $7, P>0 \cdot 1)$.

The comparatively low estimates of survival rate in the small population at West Kirby are likely to result from a high rate of emigration. This component of the rate of loss is probably relatively less important at Hightown and Hall Road (Brakefield 1982a). Estimates of expectation of life for these populations are then likely to be good estimates although tending towards underestimates, of the actual values. It therefore appears that the average life span of $M$. jurtina is in the range of 5 to 10 or 12 days (Table 3 ). The maximum life span observed in each population was 22 days which approaches that reached under favourable laboratory conditions.

TABLE 3. Estimates of 24-h survival rate and expectation of life in days (given in brackets) for Maniola jurtina

\begin{tabular}{|c|c|c|c|c|c|c|c|}
\hline \multirow[b]{2}{*}{ Population } & \multirow[b]{2}{*}{ Year } & \multicolumn{3}{|c|}{ Females } & \multicolumn{3}{|c|}{ Males } \\
\hline & & Fisher-Ford* & Jolly & Seber & Fisher-Ford & Jolly & Seber \\
\hline West Kirby & 1975 & $\begin{array}{c}0.628 \\
(2.15)\end{array}$ & $\begin{array}{c}0.494 \S \\
(1.42)\end{array}$ & - & $\begin{array}{c}0.741 \\
(3.34)\end{array}$ & $\begin{array}{l}0.686 \S \\
(2.65)\end{array}$ & - \\
\hline Hightown & 1976 & $\begin{array}{c}0.858 \\
(6.54)\end{array}$ & $\begin{array}{r}0.839 \\
(5.70)\end{array}$ & $\begin{array}{r}0.858 \\
(6.54)\end{array}$ & $\begin{array}{c}0.802 \\
(4.53)\end{array}$ & $\begin{array}{c}0.872 \\
(7.30)\end{array}$ & $\begin{array}{r}0.815 \\
(4.88)\end{array}$ \\
\hline Hightown & 1977 & $\begin{array}{c}0.836 \\
(5.59)\end{array}$ & - & - & $\begin{array}{c}0.890 \\
(8.56)\end{array}$ & $\begin{array}{c}0.870 \\
(7.18)\end{array}$ & $\begin{array}{c}0.892 \\
(8.71)\end{array}$ \\
\hline Hightown & 1978 & $\begin{array}{c}0.899 \\
(9.44)\end{array}$ & - & - & $\begin{array}{r}0.931 \\
(13.90)\end{array}$ & $\begin{array}{c}0.961^{\dagger} \\
(25.13)\end{array}$ & $\begin{array}{l}0.953 \\
(20.95)\end{array}$ \\
\hline Hall Road & 1978 & & & & $\begin{array}{r}0.941 \\
(16.41)\end{array}$ & $\begin{array}{c}0.908 \\
(10.36)\end{array}$ & $\begin{array}{r}0.887 \\
(8.37)\end{array}$ \\
\hline
\end{tabular}

* Expectation of life calculated using formula given by Cook, Brower \& Croze (1967). Bailey's correction was applied to Fisher \& Ford data.

+ Manly \& Parr's estimate $=0.924(12.65)$.

$\ddagger$ Calculated from a cohort of nineteen so sampling error is large.

$\$$ The separate estimates for survival rate obtained using Jolly's method included values with a low level of precision (see Begon 1979). For day $i$ this level is arbitrarily taken to be when the number of animals marked on day $i$ and subsequently recaptured is $<10$. Where $>5$ 'precise' estimates are available these alone are used in calculating the geometric means given in the table. 


\section{Reproductive behaviour in relation to survivorship}

The wing condition of the members of mating pairs $(n=52)$ of $M$. jurtina collected in the field was recorded. Observations of the rate of wing deterioration were made in the laboratory. Males captured in copula were sometimes old. In the laboratory males do not mate on the day of emergence but may then do so a number of times. Three males at Hightown were each observed to mate once, on day 2, 4 and 8 respectively, after their initial capture as freshly emerged individuals. A further male mated on days 4 and 12 . Females captured in copula were freshly emerged or less than 2 to 3 days old. Scali (1971) showed that females only pair once. In the following treatment it is assumed that females mate within $24 \mathrm{~h}$ of eclosion.

The daily egg production of each of eight females reared from larvae collected on St Martin's in the Isles of Scilly was recorded in the laboratory (mean total egg production \pm S.E. $=179 \pm 15 \cdot 2$ ). The peak of egg production occurred $2-5$ days after mating, thereafter the number laid steadily declined. Most eggs produced after about 2 weeks were infertile. Fig. 2 compares these data with the survivorship curve for females at Hightown. This 'fertility curve' suggests that by the time after eclosion corresponding to the expectation of life for females in this population (6.54 days) approximately $60 \%$ of the eggs have been laid and by 10 days, $75 \%$. The data can be used to estimate the expected number of eggs which a female will produce during its life-span at Hightown as sixty-six eggs. This represents 0.37 (i.e. $66 / 179$ ) of the mean egg production in the laboratory. Using the 24-h survival rate of 0.89 estimated by Dowdeswell, Fisher \& Ford (1949) for two large populations on Tean in the Isles of Scilly the corresponding estimates are eighty eggs or 0.46 of a female's potential egg production.

\section{The pattern of emergence}

Enough data were available in 1977 and 1978 at Hightown to investigate the pattern of emergence of adult butterflies. Fig. 3 shows a graphical analysis of the distribution. The data accord with the form expected from two (1977) or three (1978) approximately normal distributions which either overlap slightly to give an antimode(s) or are separated by a

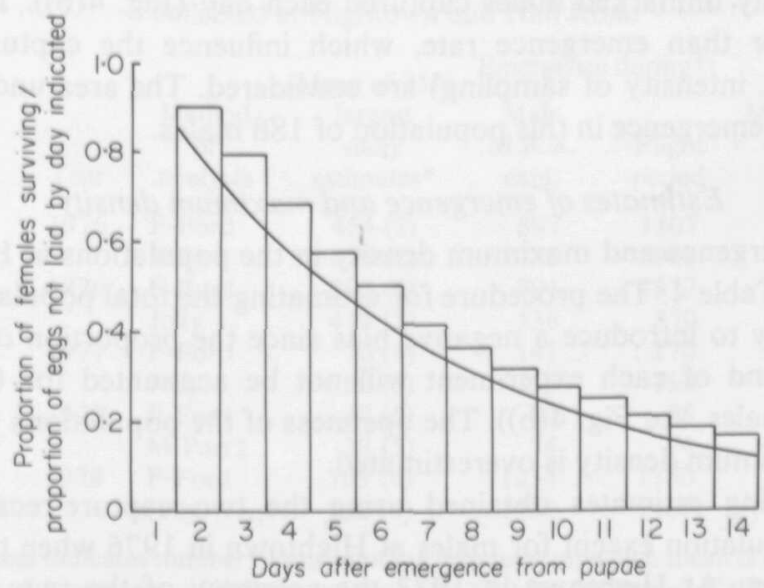

FIG. 2. Survival and fertility of female Maniola jurtina. Curve shows the probability of a female surviving to a particular time at Hightown in 1976 (Fisher \& Ford estimate, Table 3). Histogram shows the proportion of the total eggs laid by captive females of Isles of Scilly stock which remain to be oviposited after a particular interval of time. 


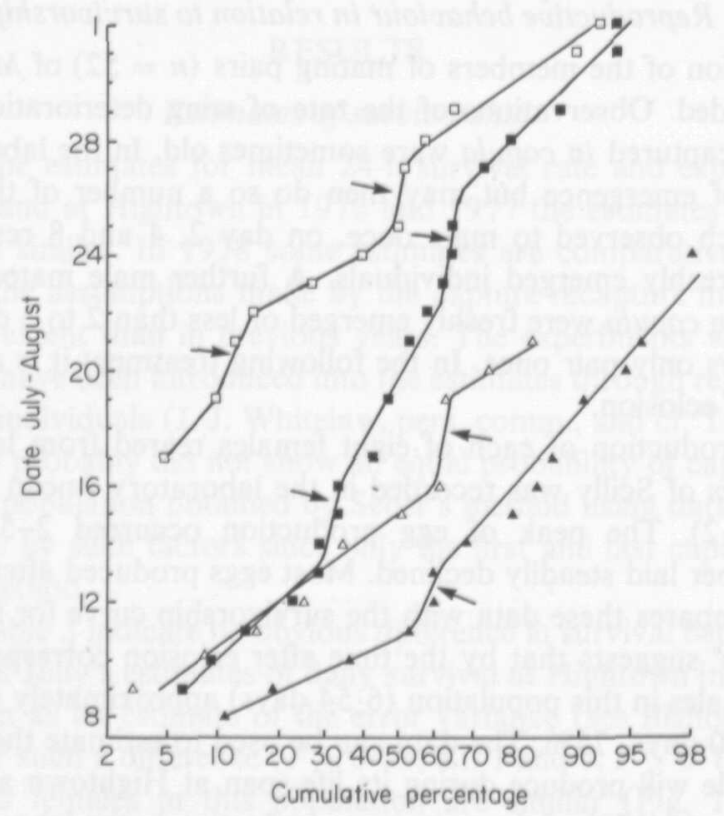

FIG. 3. Cumulative percentage of the number of freshly emerged Maniola jurtina captured at Hightown by the day indicated, plotted with the normal probability scale (from 0.02 to 0.98 ) as the abscissa. Arrows show points of inflexion in curve fitted by eye through data points. Missing data points are due to gaps in sampling. $\triangle$, females $1977 ; \square$, females $1978 ; \boldsymbol{\Lambda}$, males $1977 ; \mathbf{E}$, males 1978.

short gap(s) (Cassie 1954). Therefore, although daily sample sizes are small, these data suggest that each sex shows more than one peak of emergence.

Fig. 4 shows the emergence curve for males in 1977 estimated using statistics describing the distribution of emergence in combination with the capture-recapture data (see Fig. notes). A sharp early peak overlaps the early emergence of a smoother-contoured second peak. There is a reasonable agreement between the curve for the total emergence and the number of previously unmarked males captured each day (Fig. 4(b)). This is emphasized when factors, other than emergence rate, which influence the capture rate of freshly emerged males (e.g. intensity of sampling) are considered. The area under the curve gives an estimate of total emergence in this population of 188 males.

\section{Estimates of emergence and maximum density}

Estimates of emergence and maximum density in the populations at Hightown and Hall Road are given in Table 4. The procedure for estimating the total population emerging (see table notes) is likely to introduce a negative bias since the proportion of butterflies which emerge after the end of each experiment will not be accounted for (this proportion is usually small for males, see Fig. 4(b)). The openness of the populations (Brakefield 1982a) will mean that maximum density is overestimated.

The corresponding estimates obtained using the two capture-recapture models are similar in each population except for males at Hightown in 1976 when the experiment was comparatively short. At Hightown in 1977 the accuracy of the two estimates for total emergence of males of 170 and 158 is confirmed by that of 188 obtained from analysis of the pattern of emergence. The results suggest that a similar number of males and females emerged at Hightown in 1976. 


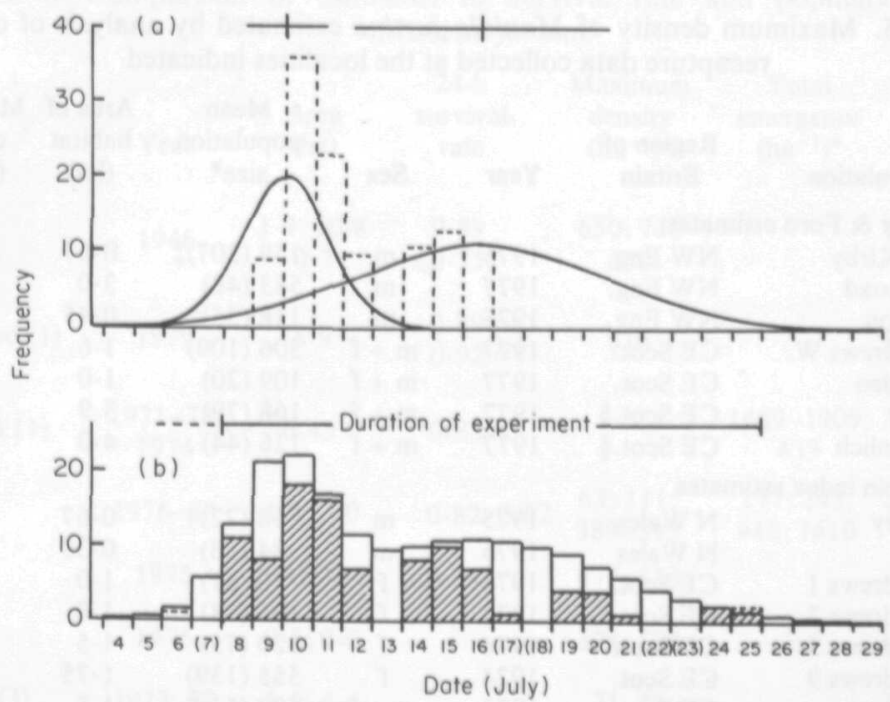

FIG. 4. Emergence pattern of male Maniola jurtina at Hightown in 1977. In (a) dashed histogram shows the estimates for emergence on dates when $\geqslant 0.5$ of the flying population was sampled on day $i$ and day $i-1$. Each was given by $\mathrm{B}_{i} / \mathrm{SF}_{i}$ where $\mathrm{B}_{i}$ is the number of unmarked males captured on day $i$ and $\mathrm{SF}_{i}$ is the estimated sampling fraction on day $i$ (see Table 1). The positions of the mean $( \pm$ S.D.) for each peak of emergence are shown (from analysis of Fig. 3, see Cassie 1954). The mean for the second peak can be estimated as the emergence on the appropriate date. The normal distribution about this mean is then generated ( - ). When estimating the mean for the first peak (prior to generating its distribution) allowance is made for the emergence of the second peak with which it overlaps. In (b) the distributions for each peak are combined to give a histogram for total emergence. The obliquely shaded portion represents $\mathbf{B}_{i}$ (1 male was also seen on July 6). Dates on which wet or overcast weather nearly or completely prevented sampling are indicated in brackets.

TABLE 4. Maximum population size and density, and emergence of male and female Maniola jurtina estimated by analysis of multiple capture-recapture data collected at Hightown and Hall Road

\begin{tabular}{|c|c|c|c|c|c|c|c|c|}
\hline \multirow[b]{2}{*}{ Population } & \multirow[b]{2}{*}{ Sex } & \multirow[b]{2}{*}{ Year } & & \multirow[b]{2}{*}{$\begin{array}{c}\text { Mean of } 25 \% \\
\text { largest } \\
\text { daily } \\
\text { estimates* }\end{array}$} & \multicolumn{2}{|c|}{ Emergence during $\dagger$ : } & \multirow[b]{2}{*}{$\begin{array}{c}\text { Maximum } \\
\text { density } \\
\left(\mathrm{ha}^{-1}\right)\end{array}$} & \multirow[b]{2}{*}{$\begin{array}{c}\text { Total } \\
\text { emergence } \\
\left(\text { ha }^{-1}\right)\end{array}$} \\
\hline & & & $\begin{array}{l}\text { Method } \\
\text { of } \\
\text { analysis }\end{array}$ & & $\begin{array}{c}\text { Main } \\
\text { M.R.R. } \\
\text { expt. }\end{array}$ & $\begin{array}{l}\text { Flight } \\
\text { period }\end{array}$ & & \\
\hline \multirow[t]{2}{*}{ Hightown } & females & 1976 & F-Ford & $454(3)$ & 897 & 1107 & 337.6 & $826 \cdot 1$ \\
\hline & & & Jolly & $420(2)$ & 770 & 963 & 313.9 & 718.7 \\
\hline \multirow[t]{2}{*}{ Hightown } & males & 1976 & F-Ford & 297 (3) & 891 & 1377 & 221.6 & 1027.6 \\
\hline & & & Jolly & $418(2)$ & 536 & 870 & 312.5 & $649 \cdot 3$ \\
\hline \multirow[t]{2}{*}{ Hightown } & males & 1977 & F-Ford & $70(4)$ & 141 & 170 & 51.9 & 125.8 \\
\hline & & & Jolly & $80(3)$ & 155 & 158 & 59.0 & 116.9 \\
\hline \multirow[t]{2}{*}{ Hightown } & males & 1978 & F-Ford & $48(5)$ & 83 & 85 & $35 \cdot 3$ & 62.6 \\
\hline & & & M-Parr $\ddagger$ & $38(5)$ & 74 & 74 & $28 \cdot 1$ & 54.5 \\
\hline \multirow[t]{2}{*}{ Hall Road } & males & 1978 & F-Ford & $709(4)$ & 1234 & 1360 & $236 \cdot 4$ & 453.3 \\
\hline & & & Jolly & $552(4)$ & 1439 & 1467 & $184 \cdot 1$ & 489.0 \\
\hline
\end{tabular}

* Figure in parentheses indicates number of unsmoothed estimates on which mean is based.

+ Gaps in the series of $k$ estimates of daily population size $\left(\mathbf{P}_{i}\right)$ for the period of the mark-release-recapture experiment are filled using a third order harmonic running mean. The late population curve (see Table 1) is estimated as $\frac{1}{2}\left(\mathrm{P}_{k-1}+\mathrm{P}_{k}\right)$ multiplied sequentially by the estimated $24-\mathrm{h}$ survival rate. The series is truncated at 10 (Hightown) or 100 (Hall Road) to make some allowance for the observed senescence. Emergence is estimated using the formula given by Blower, Cook \& Bishop (1981).

$\ddagger$ See Table 3 and text. 
TABLE 5. Maximum density of Maniola jurtina estimated by analysis of capturerecapture data collected at the localities indicated

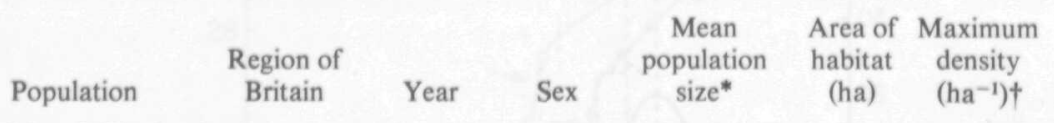

(a) Fisher \& Ford estimates

$\begin{array}{lllllll}\text { West Kirby } & \text { NW Eng. } & 1975 & \mathrm{~m} & 159(307) \ddagger & 0.67 & 477 \\ \text { Hall Road } & \text { NW Eng. } & 1977 & \mathrm{~m} & 583(48) & 3.0 & 389 \\ \text { Moreton } & \text { NW Eng. } & 1975 & \mathrm{~m} & 118(35) \ddagger & 0.45 & 533 \\ \text { St Andrews W. } & \text { CE Scot. } & 1977 & \mathrm{~m}+\mathrm{f} & 306(109) & 1.6 & 190 \\ \text { Petterden } & \text { CE Scot. } & 1977 & \mathrm{~m}+\mathrm{f} & 109(20) & 1.0 & 109 \\ \text { Clunie } & \text { CE Scot. } \S & 1977 & \mathrm{~m}+\mathrm{f} & 168(79) & 3.9 & 43 \\ \text { Duntanlich } & \text { CE Scot. } \S & 1977 & \mathrm{~m}+\mathrm{f} & 126(44) & 4.0 & 31\end{array}$

(b) Lincoln index estimates

$\begin{array}{lllllll}\text { Buckley } & \text { N Wales } & 1975 & \mathrm{~m} & 58(22) \uparrow & 0.67 & 174 \\ \text { Mold } & \text { N Wales } & 1975 & \mathrm{~m} & 84(28) & 0.33 & 504 \\ \text { St Andrews 1 } & \text { CE Scot. } & 1974 & \mathrm{f} & 170(81) & 1.0 & 340 \\ \text { St Andrews 3 } & \text { CE Scot. } & 1974 & \mathrm{f} & 105(38) & 1.0 & 210 \\ \text { St Andrews 5 } & \text { CE Scot. } & 1974 & \mathrm{f} & 220(75) & 1.5 & 293 \\ \text { St Andrews 9 } & \text { CE Scot. } & 1974 & \mathrm{f} & 555(139) & 1.75 & 634 \\ \text { Easthaven } & \text { CE Scot. } & 1973 & \mathrm{~m}+\mathrm{f} & 188(51) \uparrow & 1.5 & 125 \\ \text { Milour Moor } & \text { CE Scot. } & 1974 & \mathrm{~m}+\mathrm{f} & 480(103) \uparrow & 1.67 & 287 \\ \text { Torrie Forest } & \text { CE Scot. } & 1974 & \mathrm{~m}+\mathrm{f} & 481(165) \uparrow & 3.5 & 137 \\ \text { Lundie Craggs } & \text { CE Scot. } & 1977 & \mathrm{~m}+\mathrm{f} & 72(28) & 0.3 & 241 \\ \text { River Lyon } & \text { CE Scot. \& } & 1973 & \mathrm{~m}+\mathrm{f} & 176(38) \uparrow & 4.4 & 40\end{array}$

* In part (a) figures in parentheses indicate the total days survived by marks. In part (b) they give the S.E.

+ Calculated from twice the estimated population size for one sex or from that for the sexes combined.

¥ Calculated from the estimates obtained in the mid flight period.

$\S$ Localities in the eastern Grampian Mountains. Details of all populations are given in Brakefield (1979).

I The time lapse between the samples was $>1$ day. Allowance made for loss of marks by assuming (see Seber 1973) a 24-h survival rate of 0.9 for marked insects (see Table 3).

Estimates of maximum density obtained from short capture-recapture experiments performed with $M$. jurtina during the mid flight season in other populations near Liverpool and also in central-eastern Scotland are given in Table 5. The multiple capture-recapture data were analysed by Fisher \& Ford's method. When populations were sampled on only two dates a Lincoln Index with Bailey's correction applied was calculated.

The maximum density for males plus females of fifty-five to seventy insects ha ${ }^{-1}$ (with an emergence of $110-125$ insects $\mathrm{ha}^{-1}$ ) at Hightown in 1978 was the lowest estimate obtained for a population in England. The highest maximum density of $550-650$ insects ha ${ }^{-1}$ (emergence $=1400-1850$ insects $\mathrm{ha}^{-1}$ ) was found at Hightown in 1976. Field observations suggest that the flight period of the species is, on average, about 1-2 weeks shorter in central Scotland than in north-west England. One effect of this will be that in populations of similar maximum density that in England is likely to have a higher total emergence per unit area. The estimates indicate that the density (in terms of maximum density and emergence) of M.jurtina in populations is lower in Scotland than in England (Tables 4 and 5).

\section{DISCUSSION}

The available estimates of mean 24-h survival rate for adults of each sex in English populations range from about 0.82 to 0.92 giving an expectation of life of between 5 and 
TABLE 6. Comparison of estimates of survival rate and population size of Maniola jurtina

\begin{tabular}{|c|c|c|c|c|c|c|}
\hline $\begin{array}{l}\text { Population } \\
\qquad(n)\end{array}$ & Year & $\begin{array}{l}\text { Area } \\
\text { (ha) }\end{array}$ & $\begin{array}{l}\text { 24-h } \\
\text { survival } \\
\text { rate }\end{array}$ & $\begin{array}{l}\text { Maximum } \\
\text { density } \\
\left(\mathrm{ha}^{-1}\right)^{*}\end{array}$ & $\begin{array}{l}\text { Total } \\
\text { emergence } \\
\left(\mathrm{ha}^{-1}\right)^{*}\end{array}$ & Reference \\
\hline $\begin{array}{l}\text { Isles of Scilly: } \\
\text { Tean (2) } \\
\text { (1) } \\
\text { E. England: }\end{array}$ & 1946 & $\begin{array}{c}1.9 ; 10.8 \\
0.7\end{array}$ & $\begin{array}{r}0.89 \\
\leqslant 0.75\end{array}$ & $\begin{array}{c}650: 740 \\
360\end{array}$ & & $\begin{array}{l}\text { Dowdeswell, Fisher } \\
\text { \& Ford } 1949\end{array}$ \\
\hline $\begin{array}{l}\text { Monks Wood (1) } \\
\text { C. England: }\end{array}$ & 1979 & 5.9 & $\begin{array}{l}0.89(\mathrm{~m}) \\
0.92(\mathrm{f})\end{array}$ & 816 & & Pollard 1981 \\
\hline $\begin{array}{l}\text { Wyre Forest (1) } \\
\text { NW. England: }\end{array}$ & $\begin{array}{c}1971-73 \\
1974\end{array}$ & 0.45 & 0.85 & & $\begin{array}{c}1459-1909 ; \\
433\end{array}$ & $\begin{array}{l}\text { Tudor \& Parkin } \\
\quad 1979\end{array}$ \\
\hline $\begin{array}{l}\text { NW. England: } \\
\text { (2) }\end{array}$ & $1976-78$ & $1.4 ; 3.0$ & $0.82-0.92$ & $\begin{array}{l}63 ; 111 \\
389-593\end{array}$ & $\begin{array}{l}177: 243 ; \\
942 ; 1610\end{array}$ & This study \\
\hline N. Wales: & 1975 & $0.45 ; 0.7$ & $\leqslant 0.74$ & $477: 533$ & & \\
\hline & 1975 & $0.3 ; 0.7$ & & $174 ; 504$ & & This study \\
\hline $\begin{array}{l}\text { Grampians (3) } \\
\text { Sidlaw Hills (2) }\end{array}$ & $\begin{array}{c}1973 ; 77 \\
1977\end{array}$ & $\begin{array}{l}3.9-4.4 \\
0.3: 1.0\end{array}$ & & $\begin{array}{c}31-43 \\
109 ; 241\end{array}$ & & This study \\
\hline $\begin{array}{l}\text { Sites at lower } \\
\text { altitudes (8) }\end{array}$ & $1973-77$ & $1 \cdot 0-3 \cdot 5$ & & $\begin{array}{l}137 ; 190- \\
340 ; 634\end{array}$ & & \\
\hline
\end{tabular}

12 days (Table 6). Tudor \& Parkin (1979) found evidence that survival declined during the flight period. This was not found in the present study but the experiments did not sample the late flight period. However, the results indicate that this observation could be due to a changing age structure in combination with senescence of older butterflies.

Dowdeswell, Fisher \& Ford (1949) obtained a lower estimate for 24-h survival rate for a population occupying a small area on Tean than for two large populations (Table 6). This low estimate is similar to those obtained at West Kirby. These estimates probably include a large negative bias due to a high rate of emigration.

Cook, Frank \& Brower (1971) tabulated estimates of 24-h survival rate available for British diurnal Lepidoptera including two species of Satyrid butterflies. They comment from these estimates that the modal rate for diurnal Lepidoptera with a more or less colonial population structure in temperate regions may be 0.80 . In comparison with this the estimates for $M$. jurtina are rather high. They are more similar to the range of estimates for N. American species of butterflies obtained by Scott (1974). Sheppard (1951) examined in detail the fecundity and mortality of the colonial, day-flying moth Panaxia dominula. It can be calculated from Sheppard's data that adult mortality, on average, accounts for $68 \%$ of a female's potential egg production. The estimate is of a similar order to those obtained for M.jurtina (54\% and $63 \%)$.

In 1978 the survivorship curves for males were similar in two neighbouring populations which differed markedly in adult density and habitat. Adult survival in the population at Hightown was higher in the cool and damp summers of 1977 and 1978 than in 1976 when hot and dry conditions prevailed. The latter conditions resulted in long periods of flight activity each day, which may then have led to a faster rate of wing deterioration and a more rapid exhaustion of energy reserves (see Watt, Hoch \& Mills 1974; Brown \& Chippendale 1974). A similar influence of weather on adult survival in different years has 
been suggested by Scott (1974) for several N. American species of butterflies. Douwes (1970) found that most of the gain to, and loss from, a male population of Heodes virgaureae occurred during periods of warm and sunny weather when butterfly activity was high.

Values of emergence ha $\mathrm{a}^{-1}$ obtained for populations in England range from about 120 to 1900 insects (Table 6). The estimates for populations near Liverpool (see Table 4) suggest that the ratio of maximum density to emergence is about 0.4 . My estimates for maximum density in some populations in central-eastern Scotland suggest a generally lower population density in this area than in England. The lowest estimates were obtained for three widely dispersed populations in the Grampian Mountains. M. jurtina approaches the northern limit of its distribution in central Scotland. The largest population for which estimates have been obtained is in the Isles of Scilly (Table 6).

There was an approximately seven-fold decrease in adult emergence at Hightown from 1976 to 1977. Unfavourable conditions for larval establishment and feeding following hatching probably occurred during the extremely dry summer of 1976 . A dry environment will accentuate the normally low moisture and high fibre content of many grasses (Watson 1951). Some estimates of larval density in a population in the Isles of Scilly suggest that the early larval instars are associated with a relatively high mortality (Brakefield 1979). Laboratory observations indicate that first instar larvae are particularly susceptible to low food quality. A wetter habitat at Hall Road than at nearby Hightown probably buffered this population against the detrimental conditions of 1976 since a high adult density occurred in the subsequent 2 years.

Pollard (1979) found considerable geographical variability in the timing and length of the flight period of $M$. jurtina. It is greatly extended on sites with chalk soils. Similarly long flight periods occur in the Isles of Scilly (Ford 1975) and on the Isle of Wight (Thomson 1971). Differences between years also occur at individual sites. The emergence curve of each sex at Hightown showed a bi- or polymodal form. The peaks in female emergence were later than in males (Fig. 3). The adults reared by Dowdeswell (1962) from wild-collected late instar larvae showed two peaks of emergence in each sex. The polymodal pattern of emergence observed at Hightown may be due to direct climatic effects on larval development. However, the genetic variation in larval development rate detected by Brakefield (1982b) could also be involved. The Saturniid moth Hyalophora cecropia shows a bimodal emergence pattern which is genetically determined (Waldbauer \& Sternberg 1973). Waldbauer (1978) discusses the selective factors which will determine the timing and pattern of emergence. The predictability of the environment from one generation to another in relation to larval establishment following hatching will be an important factor in M. jurtina.

In the experiments performed by Dowdeswell, Fisher \& Ford (1949) butterflies were released at a central point in each site. Their estimates of population parameters are likely to be distorted due to effects of artificial crowding. All the populations cited in Table 6 were open: immigration and emigration occurred across the perimeter (e.g. Brakefield 1982a). This will introduce an error into the capture-recapture data. The probable existence of individual variation in dispersal behaviour (Brakefield 1982a, b) and of unequal catchability (this study) will likewise mean that the estimates include a bias. However, although the data are limited, the estimates obtained from them provide a more detailed ecological understanding of $M$. jurtina relevant to interpreting the significance of the considerable phenotypic variation exhibited by this species (reviews by Ford 1975; Brakefield 1982b). The new data now collected on (i) adult survivorship and density (this 
study), (ii) dispersal and migration (Brakefield 1982a), and (iii) family size in laboratory cultures (Brakefield 1982b) provide a starting point for obtaining estimates of the panmictic unit and the effective population size. This will be essential for a full understanding of the ecological genetics of M. jurtina.

\section{ACKNOWLEDGMENTS}

I am indebted to Professor P. M. Sheppard and Dr J. A. Bishop for supervision in the course of this work. Professor W. H. Dowdeswell and Dr E. Pollard read an early typescript. The field work was supported by a studentship from the Science Research Council. I wish to thank Professor W. Scharloo and the Department of Population and Evolutionary Biology at Utrecht for facilities provided during the writing of these papers.

\section{REFERENCES}

Begon, M. (1979). Investigating Animal Abundance. Edward Arnold, London.

Bishop, J. A. \& Hartley, D. J. (1976). The size and age structure of rural populations of Rattus norvegicus containing individuals resistant to the anticoagulant poison Warfarin. Journal of Animal Ecology, 45, $623-646$.

Bishop, J. A. \& Sheppard, P. M. (1973). An evaluation of two capture-recapture models using the technique of computer simulation. The Mathematical Theory of the Dynamics of Biological Populations (Ed. by M. S. Bartlett \& R. W. Hiorns), pp. 235-252. Academic Press, London.

Blower, J. G., Cook, L. M. \& Bishop, J. A. (1981). Estimating the Size of A nimal Populations. George Allen \& Unwin, London.

Brakefield, P. M. (1979). An experimental study of the maintenance of variation in spot pattern in Maniola jurtina. Unpublished $\mathrm{Ph}$. D. thesis, University of Liverpool.

Brakefield, P. M. (1982a). Ecological studies on the butterfly Maniola jurtina in Britain. I. Adult behaviour, microdistribution and dispersal. Journal of Animal Ecology, 51, 713-726.

Brakefield, P. M. (1982b). The ecological genetics of quantitative characters in Maniola jurtina and other butterflies. Symposia of the Royal Entomological Society, 11. The Biology of Butterflies, (in press).

Brown, J. J. \& Chippendale, G. M. (1974). Migration of the monarch butterfly Danaus plexippus: energy sources. Journal of Insect Physiology, 20, 1117-1130.

Cassie, R. M. (1954). Some uses of probability paper in the analysis of size frequency distributions. Australian Journal of Marine and Freshwater Research, 5, 513-522.

Cook, L. M., Brower, L. P. \& Croze, H. J. (1967). The accuracy of a population estimation from multiple recapture data. Journal of Animal Ecology, 36, 57-60.

Cook, L. M., Frank, K. \& Brower, L. P. (1971). Experiments on the demography of tropical butterflies. I. Survival rate and density in two species of Parides. Biotropica, 3, 17-20.

Douwes, P. (1970). Size of, gain to and loss from a population of adult Heodes virgaureae L. (Lep., Lycaenidae). Entomologia Scandinavica, 1, 263-280.

Dowdeswell, W. H. (1962). A further study of the butterfly Maniola jurtina in relation to natural selection by Apanteles tetricus. Heredity, 17, 513-523.

Dowdeswell, W. H., Fisher, R. A. \& Ford, E. B. (1949). The quantitative study of populations of the Lepidoptera. 2. Maniola jurtina L. Heredity, 3, 67-84.

Fisher, R. A. \& Ford, E. B. (1947). The spread of a gene in natural conditions in a colony of the moth Panaxia dominula (L.). Heredity, 1, 143-174.

Ford, E. B. (1975). Ecological Genetics (fourth edn). Chapman and Hall, London.

Jolly, G. M. (1965). Explicit estimates from capture-recapture data with both death and immigration-stochastic model. Biometrika, 52, 225-247.

Leslie, D. H. (1958). Statistical appendix. Journal of Animal Ecology, 27, 84-86.

Manly, B. J. F. (1970). A simulation study of animal population estimation using the capture-recapture method. Journal of Applied Ecology, 7, 13-40.

Manly, B. J. F. \& Parr, M. J. (1968). A new method of estimating population size, survivorship and birth rate from capture-recapture data. Transactions of the Society for British Entomology, 18, 81-89.

Pollard, E. (1979). A national scheme for monitoring the abundance of butterflies: the first three years. Proceedings of the British Entomological and Natural History Society, 12, 77-90.

Pollard, E. (1981). Aspects of the ecology of the meadow brown butterfly, Maniola jurtina (L.) (Lepidoptera: Satyridae). Entomologist's Gazette, 32, 67-74. 
Scali, V. (1971). Imaginal diapause and gonadal maturation of Maniola jurtina (Lepidoptera, Satyridae) from Tuscany. Journal of Animal Ecology, 40, 467-472.

Scott, J. A. (1974). Lifespan of butterflies. Journal of Research on the Lepidoptera, 12, 225-230.

Seber, G. A. F. (1973). The Estimation of Animal Abundance and Related Parameters. Griffin, London.

Sheppard, P. M. (1951). A quantitative study of two populations of the moth Panaxia dominula (L.) Heredity, 5, 349-378.

Sheppard, P. M. \& Bishop, J. A. (1973). The study of populations of Lepidoptera by capture-recapture methods. Journal of Research on the Lepidoptera, 12, 135-144.

Thomson, G. (1971). The possible existence of temporal sub-speciation in Maniola jurtina (L.). Entomologist's Record \& Journal of Variation, 83, 87-90.

Tudor, O. \& Parkin, D. T. (1979). Studies on phenotypic variation in Maniola jurtina (Lepidoptera: Satyridae) in the Wyre Forest, England. Heredity, 42,91-104.

Turner, J. R. G. (1971). Experiments on the demography of tropical butterflies. II. Longevity and home-range behaviour in Heliconius erato. Biotropica, 3, 21-32.

Waldbauer, G. P. (1978). Phenological adaptation and the polymodal emergence patterns of insects. Evolution of Insect Migration and Diapause (Ed. by H. Dinglè), pp. 127-144. Springer-Verlag, Berlin.

Waldbauer, G. P. \& Sternberg, J. G. (1973). Polymorphic termination of diapause by cecropia: genetic and geographical aspects. Biological Bulletin, 145, 627-641.

Watson, S. J. (1951). Grassland and Grassland Products. Edward Arnold, London.

Watt, W. B., Hoch, P. C. \& Mills, S. G. (1974). Nectar resource use by Colias butterflies: chemical and visual aspects. Oecologia (Berlin), 14, 353-374.

(Received 8 July 1981) 